\begin{tabular}{|cc|c|c|c|c} 
VOSDANO NOLUME & NOMOR & HALAMAN & NOVEMBER & ISSN \\
& II & 2 & $188-370$ & 2016 & $2442-9864$
\end{tabular}

IJURNALAKADEMITIK

PENDIDIILAN MIATEMIATIIEA

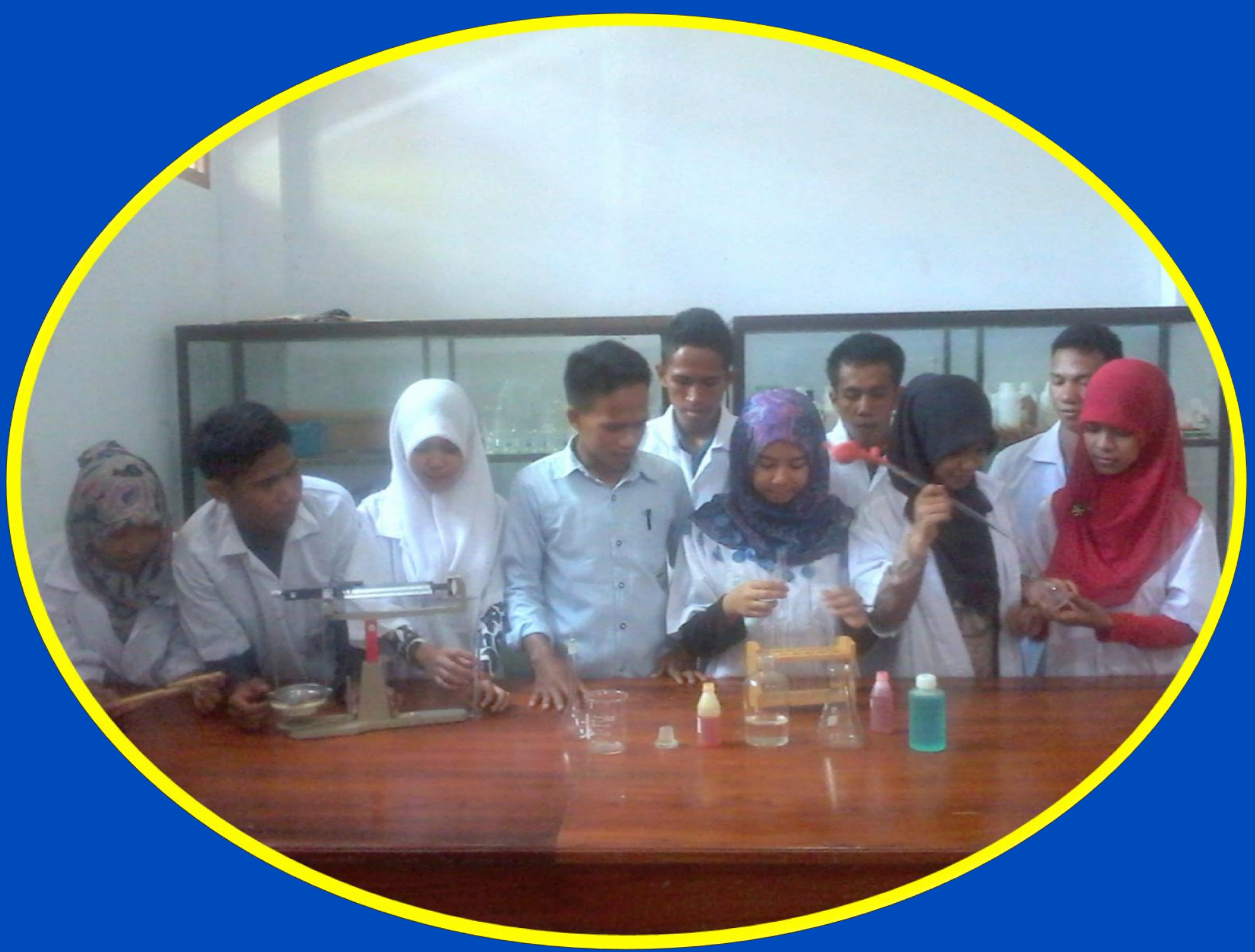

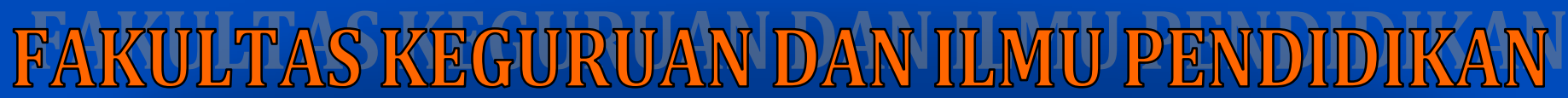

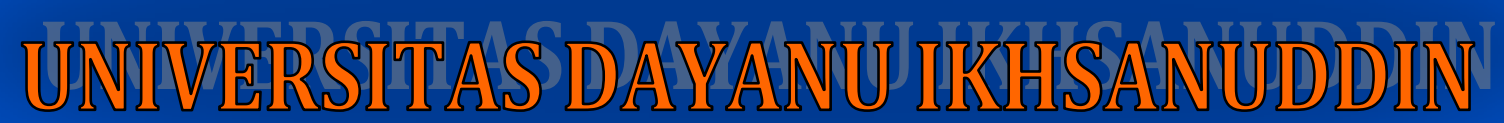

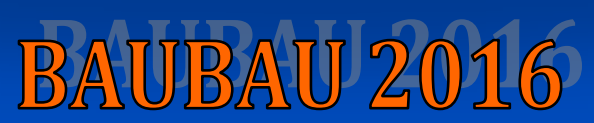




\section{PENGELOLA REDAKSI}

\section{Pembina/Penasehat}

Drs. Anwar, M.Pd.

\section{Pengarah}

Dr. Rasmuin BM., M.Pd.

\section{Pimpinan Redaksi}

Ernawati Jais, S.Si., M.Pd.

Sekretaris

Afudin La Arua, S.Pd.

\section{Penyunting}

Dian Lestari, S.Pd., M.Pd.

La Eru Ugi, S.Pd., M.Pd.

\section{Sirkulasi}

Hasan Djidu, S.Pd.

Herlawan, S.Pd., M.Pd.

\section{Diterbitkan oleh}

Lembaga Jurnal Akademik Pendidikan Matematika

FKIP Unidayan Baubau

\section{Alamat Redaksi}

Jl. Dayanu Ikhsanuddin No. 24 Baubau Telp./Fax.

E-mail. Jurnal.penmatefkipund@gmail.com 


\section{KATA PENGANTAR}

Puji syukur kita panjatkan ke hadirat Tuhan Yang Maha Pemurah dan Pengasih karena atas rahmat-Nya Jurnal Akademik Pendidikan Matematika Fakultas Keguruan dan Ilmu Pendidikan Universitas Dayanu Ikhsanuddin Baubau dapat menerbitkan Jurnal Akademik Pendidikan Matematika Volume II, Nomor 2, November 2016.

Jurnal Akademik Pendidikan Matematika memuat dan menyebar luaskan hasil-hasil penelitian pendidikan dosen, penelitian mahasiswa, penelitian guru, dan penelitian pemerhati pendidikan dari berbagai perguruan tinggi ataupun instansi di Indonesia. Hasil-hasil penelitian yang disampaikan pada jurnal ini hanya terbatas pada bidang matematika dan pendidikan matematika.

Jurnal ini adalah terbitan keempat pada Jurnal Akademik Pendidikan Matematika Fakultas Keguruan dan Ilmu Pendidikan Universitas Dayanu Ikhsanuddin Baubau, olehnya itu Pengelola Redaksi mengharapkan masukan dan kritik membangun dari civitas akademika agar terbitan berikutnya akan makin baik dan berkualitas. Adanya kekurangan-kekurangan pada jurnal ini kiranya dapat dimaklumi.

Atas perhatian pembaca dan semua pihak yang telah memberikan bantuan hingga diterbitkannya jurnal ini diucapkan terima kasih.

Baubau, November 2016

Kaprodi Pend. Matematika,

ttd

Ernawati Jais, S.Si., M.Pd.

NIDN. 0923118003 


\section{DAFTAR ISI}

Pengelola Redaksi

ii

Kata Pengantar

Daftar Isi

iii

iv

Peningkatan Hasil Belajar Menggambar Fungsi Kuadrat Melalui Model Pembelajaran Missiouri Mathematics Project dan Aplikasi Geogebra Siswa Kelas XI Budidaya Perikanan

Oleh: Amlin

Peningkatan Pemahaman Menghitung Perkalian dengan Media Benda-Benda Terdekat pada Siswa Kelas IV SD Negeri 1 Wajo Tahun Ajaran 2013/2014

Oleh: Musryhawaty H.M.

Pengaruh Motivasi, Sikap, Minat, dan Gaya Belajar Statistik Mahasiswa Terhadap Kemampuan Menganalisis Persoalan Penelitian

Oleh: Azis, Sardin 200-208

Meningkatkan Kemampuan Siswa dalam Mengoperasikan Penjumlahan dan Pengurangan pada Mata Pelajaran Matematika dengan Bantuan Benda-Benda Konkrit Oleh: Emi

Upaya Peningkatan Motivasi dan Prestasi Belajar Matematika pada Materi Segiempat Kelas VII SMPS Bataraguru melalui Model Pembelajaran Teams Games Tournament Oleh: Husniah

Upaya dalam Meningkatkan Pemahaman Konsep Perkalian dengan Benda-Benda Manipulatif Melalui Pendekatan Realistik di Kelas II Sekolah Dasar Negeri 2 Baadia

Oleh: Muslima 228-239

Meningkatkan Prestasi Belajar Matematika Menggunakan Kartu Bilangan dalam Pembelajaran Bilangan Bulat di Kelas IV SD Negeri 2 Lombe

Oleh: Anwar, Musnia $240-244$

Analisis Kesalahan Siswa dalam Menyelesaikan Soal-Soal Pokok Bahasan Garis Singgung Lingkaran pada Siswa Kelas VIII

Oleh: La Eru Ugi, Hety Kusniawati

Efektifitas Pembelajaran Berbasis Proyek Terhadap Kemampuan Matematika Siswa Kelas V SD Negeri 1 Nganganaumala

Oleh: Artati Iriana $250-255$

Kepraktisan LKS Pembelajaran Matematika dengan Pendekatan Problem Solving Oleh: Abdurahman Askois

Perbedaan Kemampuan Pemecahan Masalah Matematis dengan Menggunakan Pendekatan Kontekstual dan Menggunakan Pendekatan Konvensional Siswa Kelas IV SD Negeri 1 Wameo Oleh: Raden Heri Setiawan 
Penerapan Pendekatan Matematika Realistik untuk Meningkatkan Pemahaman Siswa SMK Swasta Kesehatan (SMKS) Baubau

Oleh: Rismayani Armin, LM. Yogi Prasetyawan

Efektivitas Model Konstruktivis dalam Pembelajaran Matematika pada Siswa Kelas VII SMP Neger1 1 Kadatua

Oleh: Ernawati Jais, Sutriadin

$278-285$

Meningkatkan Hasil Belajar Siswa Pokok Bahasan Operasi Hitung Campuran melalui Implementasi Pembelajaran Tutor Sebaya dan Penggunaan LKS

Oleh: Herno, Dayanti

Meningkatkan Pemahaman Konsep Luas Permukaan Bangun Ruang dengan Pendekatan Konstruktivistik pada Siswa SMP Negeri 2 Kambowa

Oleh: Suwarni La Usa, La Demo

Meningkatkan Prestasi Belajar Matematika Siswa pada Pokok Bahasan Operasi Aljabar melalui Model Pembelajaran Kooperatif Tipe Think-Pair-Share (TPS)

Oleh: Maya Nurlita, Hasmina Huzu

299-306

Meningkatkan Aktivitas Belajar dan Hasil Belajar Matematika melalui Penerapan Metode Pembelajaran Teams Games Tournament

Oleh: Dasrun

Meningkatkan Keaktifan dan Prestasi Belajar Siswa Kelas VII-3 SMP Negeri 4 Baubau pada Materi Segiempat melalui Pendekatan Inquiri

Oleh: Dian Lestari, Jeni

Peningkatan Aktivitas Belajar dan Hasil Belajar Matematika Melalui Penerapan Kombinasi Strategi Snowball Throwing dengan Perencanaan Peta Konsep

Oleh: Arabia $325-331$

Penerapan Model Pembelajaran Kepala Bernomor Struktur Untuk Meningkatkan Aktivitas Belajar dan Prestasi Belajar Matematika Siswa Kelas V

Oleh: Barudia

Meningkatkan Kemampuan Komunikasi Matematika Siswa pada Konsep Perkalian dan Pembagian Bilangan Bulat melalui Pendekatan Problem Solving

Oleh: Raisu

Penggunaan Model Pembelajaran Kooperatif Tipe Jigsaw dalam Meningkatkan Hasil Belajar Matematika Siswa Kelas V-A SD Negeri 2 Katobengke

Oleh: Habiyba $350-356$

Penerapan Model Pembelajaran Kooperatif Tipe TPS dalam Meningkatkan Hasil Belajar Matematika Siswa Kelas V-B SD Negeri 2 Katobengke

Oleh: Husnia

Penerapan Model Pembelajaran Kooperatif Tipe NHT dalam Meningkatkan Hasil Belajar Matematikasiswa Kelas IV-A SD Negeri 2 Katobengke

Oleh: Wa Ode Mbaraya $363-370$ 
Suwarni La Usa, La Demo

\title{
MENINGKATKAN PEMAHAMAN KONSEP LUAS PERMUKAAN BANGUN RUANG DENGAN PENDEKATAN KONSTRUKTIVISTIK PADA SISWA SMP NEGERI 2 KAMBOWA
}

\author{
Suwarni La Usa ${ }^{1)}$, La Demo \\ Dosen Pendidikan Matematika FKIP Unidayan Baubau ${ }^{1)}$ \\ Mahasiswa Pendidikan Matematika FKIP Unidayan Baubau ${ }^{2)}$ \\ an_nyie03@yahoo.co.id ${ }^{1)}$
}

\begin{abstract}
Abstrak
Tujuan penelitian ini adalah untuk meningkatkan pemahaman terhadap konsep luas permukaan kubus dan balok dengan menggunakan pendekatan konstruktivistik pada siswa kelas VIII SMP Negeri 2 Kambowa. Penelitian ini merupakan penelitian tindakan kelas dengan menggunakan sampel dari siswa kelas VIII SMP Negeri 2 Kambowa sebanyak 20 siswa. Cara pengambilan data dalam penelitian ini dengan mengumpulkan hasil observasi, nilai evaluasi siklus I dan nilai evaluasi siklus II. Teknik analisis data yang digunakan adalah reduksi data, display data dan penarikan kesimpulan. Sebagai tolak ukur keberhasilannya adalah apabila prestasi belajar siswa pada pokok bahasan Bangun Ruang khususnya luas permukaan kubus dan balok meningkat, yaitu nilai yang dihasilkan $\leq 65$ dan siswa yang mendapat nilai $\leq$ 65 minimal $80 \%$ dari jumlah siswa. Dari hasil analisis diperoleh bahwa nilai rata-rata pada siklus I yakni 63,50 dengan persentase ketuntasan belajar $65 \%$ sebanyak 13 siswa. Pada siklus II diperoleh nilai ratarata 77,25 dengan persentase ketuntasan belajar $90 \%$ sebanyak 18 siswa. Dengan demikian penerapan pendekatan konstruktivistik dapat meningkatkan pemahaman siswa terhadap konsep luas permukaan bangun ruang.
\end{abstract}

Kata kunci: pendekatan konstruktivistik, pemahaman konsep, luas permukaan bangun ruang

\section{Abstract}

The objective of this research was to increase the comprehension toward the concept of surface area of cube and cuboid by using constructivistic approach on students at grade VIII of SMP Negeri 2 Kambowa. This research was classroom action research with using sample from students at grade VIII of SMP Negeri 2 Kambowa which amounted to 20 students. The way of taking data in this research was by collecting observation data, evaluation score of cycle I, and evaluation score of cycle II. Technique of data analysis used was data reduction, data display, and deducing. As the standard of success was if students' learning achievement on learning topic of space figure especially the surface area of cube and cuboid was improving, that was the score was $\leq 65$ and students who got score of $\leq 65$ was $80 \%$ of the total students in minimum. Of the result of analysis, it was obtained that in cycle I was 63.50 with the learning completeness percentage was $65 \%$ or 13 students. In cycle II, it was obtained the mean score was 77.25 with the learning completeness percentage was $90 \%$ or 18 students. Therefore, the implementation of constructivistic approach could increase students' comprehension toward the surface area concept of space figure.

Keywords: constructivistic approach, concept comprehension, the area of space figure

\section{PENDAHULUAN}

Matematika adalah ilmu yang mengkaji benda abstrak yang disusun dalam suatu sistem aksiomatis dengan menggunakan simbol dan penalaran deduktif. Menurut Hudoyo (Aisyah, 2007, p.1) bahwa matematika berkenaan dengan ide atau gagasan-gagasan, aturan-aturan, hubungan yang diatur secara logis sehingga matematika berkaitan dengan konsep-konsep abstrak. Pemahaman konsep perlu dibangun untuk membangkitkan daya tanggap siswa agar keterampilan matematika dapat terkonstruksi sehingga pemahaman terhadap konsep dapat tercapai.

Menurut Hudoyo (Aisyah, 2007, p.5) belajar matematika adalah belajar mengenai konsep dalam struktur matematika yang dipelajari serta mencari hubungan antara konsep dan struktur matematika itu. Sehingga dalam belajar siswa harus benar-benar aktif mentalnya agar dapat mengenal konsep dan struktur yang tercakup dalam bahan yang tengah dipelajari sehingga 
siswa akan memahami materi agar tercapai penguasaan yang maksimal. Konsep matematika yang sangat kompleks akan cukup sulit bahkan tidak bisa dipahami jika pemahaman konsep yang lebih sederhana belum memadai. Dengan demikian pemahaman konsep matematis menjadi salah satu tujuan pembelajaran matematika.

Banyak guru Sekolah Menengah Pertama telah menggunakan berbagai metode mengajar dalam matematika untuk mengoptimalisasikan pembelajaran dalam kelas yang mengarah pada penciptaan kemampuan matematika siswa. Akan tetapi guru lebih cenderung menggunakan metode yang ceramah tanya jawab tanpa adanya pengspesifikasikan pengajaran yang mengarah ke penggalian konsep.

Berdasarkan hasil obsevasi yang dilakukan di SMP Negeri 2 Kambowa, terlihat bahwa salah satu materi pelajaran yang sulit dikuasai oleh siswa adalah pembelajaran bangun ruang. Bangun ruang merupakan salah satu bahan ajar yang dipelajari mulai dari kelas rendah sampai pada kelas tinggi dimana guru menyajikan langsung rumus luas permukaan bangun ruang tanpa menggunakan metode dan alat bantu mengajar sehingga siswa hanya bisa menerima sajian pelajaran dari guru. Sementara banyak benda atau alat yang terdapat di sekeliling siswa untuk diramu dan dimodel sehingga dapat mendekati bentuk bangun ruang yang selanjutnya dapat terkonsep untuk menemukan luas permukaan bangun ruang. Tetapi untuk mengimplementasikan benda atau alat peraga yang dapat menjabarkan konsep bangun ruang belum dikuasai sepenuhnya oleh guru. Sehingga pada saat guru memberikan latihan terkait dengan bangun ruang, siswa cukup mencarinya dengan menggunakan rumus yang telah diberikan oleh guru sejak menyajian awal pelajaran. Ini menunjukkan bahwa siswa relatif pasif terhadap pembelajaran yang diberikan oleh guru dikarenakan tidak adanya peletakan dasar rumus luas permukaan bangun ruang melalui alat peraga yang ada.

Materi Bangun Ruang merupakan materi yang cocok bila diajarkan dengan menerapkan pendekatan konstruktivistik karena pembelajaran konstruktivistik merupakan suatu kondisi dimana guru membantu siswa untuk membangun pengetahuan dengan kemampuannya sendiri melalui konsep internalisasi sehingga pengetahuan itu dapat terkonstruksi kembali. Hal ini sejalan dengan Anders (Wardani, 1999, p.5) bahwa konstruktivistik adalah pandangan tentang belajar mengajar yang menempatkan pelajar sendiri arti atau pengetahuan dan pengalaman dan interaksi dengan yang lain dan peranan guru menyediakan pengalaman yang berarti bagi siswa. Ciri-ciri pembelajaran matematika sesuai pandangan konstruktivistik antara lain 1) siswa terlibat aktif dalam belajarnya; 2) informasi baru harus dikaitkan dengan informasi lain sehingga menyatu dengan jaringan konsep yang dimiliki siswa; 3) orientasi pembelajaran adalah investigasi dan penemuan yang pada dasarnya adalah pemecahan masalah.

Adapun langkah-langkah pembelajaran pendekatan konstruktivistik dapat dilihat pada Tabel 1 berikut. 
Suwarni La Usa, La Demo

Tabel 1. Langkah-Langkah Pembelajaran Pendekatan Konstuktivistik

\begin{tabular}{|c|c|c|c|}
\hline No & $\begin{array}{c}\text { Tahap-tahap } \\
\text { Pembelajaran } \\
\text { Konstruktivistik } \\
\end{array}$ & Aktivitas Guru & Aktivitas Siswa \\
\hline \multirow[t]{2}{*}{1.} & Tahap awal & $\begin{array}{l}\text { Melakukan kegiatan menghubungkan konsepsi } \\
\text { awal, mengungkapkan pertanyaan-pertanyaan dari } \\
\text { materi sebelumnya }\end{array}$ & $\begin{array}{l}\text { Siswa menyimak apa yang disampaikan oleh } \\
\text { guru dan menanggapi pertanyaan dari guru }\end{array}$ \\
\hline & & Guru menyampaikan tujuan pembelajaran & $\begin{array}{l}\text { Siswa menyimak apa yang disampaikan oleh } \\
\text { guru mengenai tujuan pembelajaran }\end{array}$ \\
\hline 2. & Tahap eksplorasi & $\begin{array}{l}\text { Guru memancing pengetahuan awal siswa } \\
\text { mengenai materi yang akan diajarkan siswa }\end{array}$ & $\begin{array}{l}\text { Siswa mengungkapkan dugaan sementara } \\
\text { terhadap konsep yang akan dipelajari. Kemudian } \\
\text { siswa menggali, menyelidiki dan menemukan } \\
\text { sendiri konsep sebagai jawaban dari dugaan } \\
\text { sementara yang dikemukakan pada tahap } \\
\text { sebelumnya, melalui manipulasi benda langsung }\end{array}$ \\
\hline 3. & Tahap klarifikasi & $\begin{array}{l}\text { Guru menjadi fasilitator dalam menampung dan } \\
\text { membantu siswa membuat kesepakatan kelas, } \\
\text { yaitu setuju atau tidak dengan pendapat } \\
\text { kelompok lain serta memotivasi siswa } \\
\text { mengungkapkan alasan dari kesepakatan tersebut } \\
\text { melalui kegiatan tanya jawab }\end{array}$ & $\begin{array}{l}\text { Siswa mengkomunikasikan hasil penyelidikan } \\
\text { dan temuannya }\end{array}$ \\
\hline 4. & Aplikasi konsep & $\begin{array}{l}\text { Guru mengevaluasi kegiatan pembelajaran yang } \\
\text { telah dipelajari agar bisa mengetahui apakah } \\
\text { tujuan pembelajaran telah tercapai }\end{array}$ & $\begin{array}{l}\text { Siswa mengerjakan soal evaluasi yang telah } \\
\text { diberikan oleh guru }\end{array}$ \\
\hline \multirow[t]{4}{*}{5.} & Kegiatan akhir & $\begin{array}{l}\text { Guru menyampaikan keberhasilan pembelajaran } \\
\text { secara umum }\end{array}$ & Siswa menyimak yang disampaikan oleh guru \\
\hline & & Guru dan siswa menyimpulkan materi & Siswa menyimpulkan materi \\
\hline & & Guru memotivasi siswa & $\begin{array}{l}\text { Siswa menyimak apa yang disampaikan guru } \\
\text { mengenai motivasi }\end{array}$ \\
\hline & & Guru menutup pelajaran dengan berdoa & Siswa berdoa \\
\hline
\end{tabular}

Berdasarkan latar belakang yang dikemukakan di atas, rumusan masalah dalam penelitian ini adalah apakah pemahaman terhadap konsep luas permukaan kubus dan balok dapat ditingkatkan melalui penerapan pendekatan konstruktivistik pada siswa kelas VIII SMP Negeri 2 Kambowa?

\section{METODE PENELITIAN}

\section{Jenis Penelitian}

Jenis penelitian ini adalah Penelitian Tindakan Kelas (PTK). Penelitian tindakan kelas adalah suatu penyelidikan atau kajian secara sistematis dan terencana dengan tujuan untuk memperbaiki pembelajaran dengan jalan mengadakan perbaikan atau perubahan dan mempelajari akibat yang ditimbulkan.

\section{Waktu dan Tempat Penelitian}

Penelitian ini dilaksanakan di SMP Negeri 2 Kambowa pada semester ganjil tahun ajaran 2016/2017 pada bulan Mei 2016 - bulan Agustus 2016.

\section{Subjek Penelitian}

Subyek dalam penelitian ini adalah siswa kelas VIIIa SMP Negeri 2 Kambowa yang berjumlah 20 siswa terdiri dari 8 siswa dan 12 siswi.

\section{Prosedur Penelitian}

Penelitian ini dilaksanakan dalam 2 siklus. Tiap siklus terdiri dari 2 pertemuan. Tiap siklus dilaksanakan sesuai dengan perubahan yang ingin dicapai. Kelemahan dan kekurangan setiap siklus akan diamati untuk direfleksi dan diperbaiki pada siklus berikutnya. Penelitian ini mencakup 5 tahap yakni perencanaan, pelaksanaan tindakan, observasi, evaluasi dan refleksi. Pada tahap perencanaan, kegiatan yang dilakukan adalah membuat dan menyiapkan perangkat-perangkat pembelajaran baik RPP, media pembelajaran sebagai alat bantu mengajar, lembar observasi maupun soal tes yang akan digunakan. Pada tahap pelaksanaan tindakan, kegiatan yang dilakukan adalah melaksanakan skenario pembelajaran yang telah dibuat. Pada tahap observasi, kegiatan yang dilakukan adalah mengamati guru dalam kelas selama proses pembelajaran dengan menggunakan pendekatan konstruktivistik. Pengamatan juga dilakukan terhadap perilaku dan aktivitas siswa selama proses pembelajaran berlangsung dan dampak yang ditimbulkan dari perilaku guru terhadap siswa. Pada tahap evaluasi dan refleksi, kegiatan 
yang dilakukan adalah melakukan penilaian terhadap hasil tes yang diberikan untuk melihat ketuntasan klasikal siswa sesuai dengan indikator keberhasilan yang ditetapkan untuk melanjutkan ke siklus selanjutnya atau menghentikan tindakan siklus.

\section{Instrumen dan Teknik Pengumpulan Data}

Instrumen yang digunakan dalam penelitian ini adalah (1) tes hasil belajar dalam bentuk tes essay yang diberikan pada setiap akhir tindakan siklus. Tes hasil belajar digunakan untuk melihat sejauh mana pemahaman konsep siswa terhadap materi luas permukaan bangun ruang dan (2) lembar observasi baik aktivitas siswa maupun aktivitas guru yang dilakukan selama proses pembelajaran dengan menggunakan pendekatan konstruktivistik. Lembar observasi digunakan untuk mengamati kegiatan proses pembelajaran di kelas selama penerapan pendekatan konstruktivistik.

\section{Teknik Analisis Data}

Teknik analisis data yang digunakan adalah analisis kualitatif yakni pertama reduksi data, reduksi data adalah memilih hal-hal pokok yang sesuai dengan fokus penelitian kita. Data yang telah direduksi memberikan gambaran yang lebih tajam mengenai hasil pengamatan dan mempermudah peneliti untuk mencarinya jika sewaktu-waktu diperlukan. Kedua penyajian data, menyajikan data dalam bentuk matriks, chart atau grafik, network dan sebagainya. Ketiga penarikan kesimpulan, penarikan kesimpulan atau verifikasi merupakan kegiatan di akhir penelitian.

\section{HASIL PENELITIAN DAN PEMBAHASAN}

Kegiatan awal dimulai dengan guru mengabsen siswa, melakukan apersepsi tentang materi kubus dan balok, menyampaikan langkahlangkah pembelajaran dengan pendekatan konstruktivistik. Guru mengelompokkan siswa menjadi 4 kelompok yang terdiri dari 5 orang yang dibagi secara heterogen berdasarkan kemampuan.

Pada kegiatan inti, penyajian materi dilakukan melalui tiga fase. Pada fase eksplorasi, guru membagikan alat peraga kepada semua siswa berupa karton kubus dan karton balok disertai persegi dan persegi panjang yang merupakan bidang-bidang kubus dan balok. Siswa diminta mengamati dan memanipulasi alat peraga, selanjutnya menempelkan persegi sehingga membentuk jaring-jaring. tidak. Pada fase ini masih ada sebagian siswa yang tidak dapat menyusun dengan baik.

Pada fase pengenalan konsep, guru mengarahkan siswa untuk melaporkan hasil pekerjaannya pada setiap siswa dan memberi kesempatan pada siswa yang lain untuk memberi tanggapan. Tujuan kegiatan ini adalah agar siswa dapat menemukan sendiri rumus luas permukaan kubus. Pada saat siswa melakukan kegiatan tersebut siswa berusaha menemukan hubungan antara bidang-bidang yang membentuk kubus dan balok tersebut. Sehingga ketika kegiatan usai dilakukan maka siswa dapat terkonstruk pengetahuannya berdasarkan kegiatan yang mereka lakukan. Pada fase ini masih ada siswa yang malu dan takut untuk memberikan komentar.

Pada fase aplikasi konsep bertujuan untuk memberi kesempatan kepada siswa untuk memantapkan konsep dengan menyelesaikan soal-soal luas permukaan kubus dan balok sesuai yang telah dipelajari melalui alat peraga dengan memberikan LKS kepada siswa untuk menguji kemampuan siswa terhadap kegiatan yang telah dilakukan sebelumnya. Selanjutnya masing-masing siswa melaporkan hasil pekerjaannya yang ada pada LKS dan siswa diberikan kesempatan untuk mendiskuikan dengan teman-teman yang lain. Pada kesempatan ini banyak siswa yang bertanya-tanya pada beberapa nomor soal karena soal yang disajikan berbentuk cerita tanpa adanya gambar yang disajikan.

Pada kegiatan akhir, guru dan siswa bersama-sama menyimpulkan materi yang telah dipelajari.

Pada siklus I persentase aktivitas siswa pada pertemuan pertama sebesar 71,43\% dan pertemuan kedua sebesar $76,19 \%$, dengan ratarata $73,81 \%$. Berdasarkan evaluasi siklus I, siswa yang mendapat nilai $<65$ sebanyak 7 siswa dari 20 atau 35\% sedangkan siswa yang mendapat nilai $\geq 65$ sebanyak 13 siswa atau sebesar $65 \%$ dengan nilai rata-rata kelas 63,50. Dari hasil tersebut dilihat bahwa nilai yang diharapkan masih jauh dari indikator pencapaian sehingga diharuskan untuk dilanjutkan pada siklus II.

Pada siklus II persentase aktivitas siswa pada pembelajaran pertemuan pertama mendapat nilai sebesar $90,48 \%$, sedangkan pada pertemuan kedua diperoleh persentase aktivitas siswa sebesar 95,23\%, dengan rata-rata 92,85\%. Berdasarkan hasil evaluasi siklus II, siswa mendapat nilai $<65$ sebanyak 2 orang dari 20 
siswa atau sebesar $10 \%$, sedangkan siswa yang berada mendapat nilai $\geq 65$ sebanyak 18 siswa dari 20 siswa atau sebesar $90 \%$ dengan rata-rata kelas 77,25 .

Berikut daftar tabel dan grafik pengamatan aktivitas siswa dengan menggunakan pendekatan Konstruktivistik dari siklus I ke siklus II.

Tabel 2. Aktivitas Siswa

\begin{tabular}{cccc}
\hline No & Aktivitas Siswa & Siklus I & Siklus II \\
\hline 1. & Pertemuan I & $71,43 \%$ & $90,48 \%$ \\
2. & Pertemuan II & $76,19 \%$ & $95,85 \%$ \\
\hline & Rata-rata & $73,81 \%$ & $92,85 \%$ \\
\hline
\end{tabular}

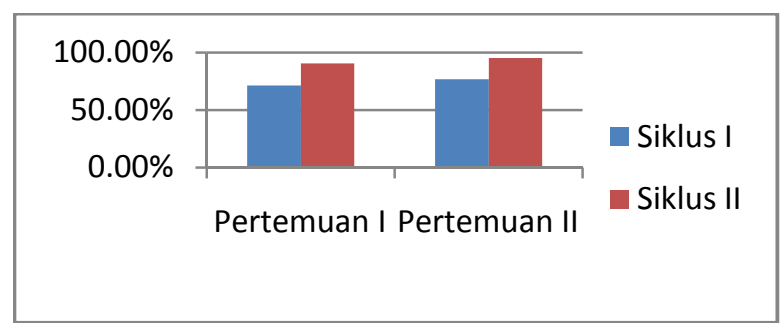

Gambar 1. Grafik Aktivitas Siswa

Berikut daftar tabel pengamatan hasil evaluasi prestasi belajar matematika siswa sebelum melakukan tindakan dan setelah tindakan dengan menggunakan pendekatan konstruktivistik dari siklus I ke siklus I.

Tabel 3. Hasil Evaluasi Prestasi Belajar Siswa

\begin{tabular}{lcc}
\hline & Siklus I & Siklus II \\
\hline Rata-rata Kelas & 63,50 & 77,25 \\
$\begin{array}{l}\text { Ketuntasan belajar } \\
\text { klasikal }\end{array}$ & $65 \%$ & $90 \%$ \\
\hline
\end{tabular}

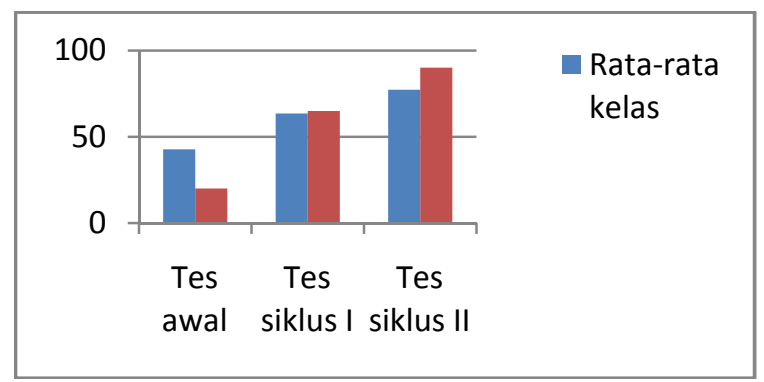

Gambar 2. Grafik Hasil Evaluasi Prestasi Belajar Siswa

Berdasarkan uraian di atas, penelitian yang dilakukan di SMP Negeri 2 Kambowa dengan menggunakan pendekatan konstruktivistik dari siklus I sampai siklus II mengalami peningkatan. Hal ini dapat diinterprestikan bahwa siswa sudah mengalami peningkatan pemahaman dalam menghubungkan suatu konsep dengan konsep yang lainnya. Dalam hal ini, siswa sudah mengalami peningkatan pemahaman terhadap materi konsep luas permukaan bangun ruang dengan baik.

Melalui pendekatan konstruktivistik dengan pembelajaran fase eksplorasi, fase penanaman konsep dan fase aplikasi konsep siswa diarahkan untuk memperoleh pemahaman tentang konsep luas permukaan bangun ruang secara konseptual maupun secara prosedural. Sebab pengetahuan konseptual mengacu pada pemahaman konsep, sedangkan pengetahuan prosedural mengacu pada keterampilan melakukan algoritma atau prosedur mengerjakan. Selain tahapan pembelajaran yang digunakan juga tak lepas dari alat peraga yang digunakan untuk membangkitkan skemata siswa dalam proses pembelajaran.

Penggunaan alat peraga dimaksudkan untuk mempermudah siswa dalam memahami konsep matematika yang bersifat abstrak. Alat peraga yang digunakan bersifat konkret agar lebih mudah digunakan oleh siswa sehingga memudahkan siswa memahami konsep matematika yang bersifat abstrak secara sederhana.

Dalam kegiatan pembelajaran siswa bekerja dengan memanipulasi benda konkret yaitu karton persegi yang dilengkapi dengan persegi satuan. Aktivitas yang dilakukan siswa adalah menempelkan persegi satuan pada bidang bangun yang besar. Kegiatan ini selain dapat menciptakan pengalaman yang menyenangkan siswa, juga dapat melibatkan siswa secara fisik dan mental dalam belajar sehingga siswa dapat membangun pengetahuannya. Pengalaman bersentuhan langsung dengan objek belajarnya menjadi sangat penting. Dengan cara ini, siswa dapat menjalani proses mengkonstruksi pengetahuan baik berupa konsep, ide maupun pengertian tentang sesuatu yang sedang dipelajarinya.

Dari kegiatan yang dilakukan siswa bersentuhan dengan alat peraga siswa dengan sadar menginterpretasi pola matematika yang terdapat dalam benda konkret tersebut. Sehingga siswa lebih mudah memahami konsep terhadap permasalahan yang tengah dihadapinya, hal ini terlihat dari hasil kerja siswa dalam LKS.

Aktivitas yang dilakukan siswa untuk menemukan konsep luas permukaan bangun ruang yang ditunjukan melalui gambar yang ada pada LKS berhubungan dengan gambaran mental dari objek yang dimanipulasinya. 
Pemahaman siswa yang baik terhadap konsep luas permukaan bangun ruang mengindikasikan bahwa pendekatan konstruktivistik memungkinkan untuk dijadikan sebagai salah satu model pembelajaran dalam meningkatkan prestasi siswa matematika khususnya di sekolah menengah pertama.

\section{KESIMPULAN DAN SARAN}

\section{Kesimpulan}

Berdasarkan analisis data dan pembahasan, maka dapat disimpulkan bahwa pemahaman siswa kelas VIII SMP Negeri 2 Kambowa terhadap konsep luas permukaan kubus dan balok dapat ditingkatkan melalui penerapan pendekatan konstruktivistik.

\section{Saran}

Saran yang diberikan sehubungan dengan hasil penelitian ini adalah sebagai berikut: 1) Untuk meningkatkan pemahaman konsep dan hasil belajar siswa-siswa secara menyeluruh, sebaiknya guru menyajikan materi pembelajaran dengan memilih pendekatan yang sesuai dengan karakteristik materi yang disajikan dalam hal ini salah satu pendekatan pembelajaran yang mudah untuk diterapkan kepada siswa-siswa adalah pendekatan konstruktivistik. 2) Kepada para peneliti berikutnya diharapkan hasil penelitian ini dapat disajikan sebagai bahan perbandingan untuk melakukan penelitian yang serupa atau lebih mengembangkan maksud dan tujuan penelitian.

\section{DAFTAR PUSTAKA}

[1] Aisyah, N. 2007. Pengembangan Pembelajaran Matematika SD. Jakarta: Depdiknas.

[2] Darhim. 1992. Work Shop Matematika. Jakarta: Depdikbud.

[3] Dafril, A. 2011. Pengaruh Pendekatan Konstruktivisme Terhadap Peningkatan Pemahaman Matematika Siswa. Palembang: Prosiding PGRI. hal 795-796.

[4] Inganah, S. 2003. Model Pembelajaran Segi Empat Dengan Pendekatan Realistik Pada Siswa Kelas 2SLTP Negeri 3 Batu. Tesis, tidak diterbitkan. Universitas Negeri Malang.
[5] Kesumawati. 2008. Pemahaman Konsep Matematika dalam Pembelajaran Matematika. Jakarta : Depdiknas.

[6] Muhsetyo, G., dkk. 2005. Pembelajaran Matematika SD. Jakarta: Universitas Terbuka.

[7] Rakhmat, C. 1998. Evaluasi Pengajaran. Jakarta: Depdikbud.

[8] Soewito, dkk. 1991. Pendidikan Matematika I. Jakarta: Depdikbud.

[9] Suparno, P. 2001. Filsafat Konstruktivistikme dalam Pendidikan. Kanisius: Yogyakarta.

[10] Wardhani, S. 1999. Konstruktivistikme. Jakarta: Depdikbud.

[11] Yuwono, I. 2001. Pembelajaran Matematika Secara Membumi. Universitas Negeri Malang: Depdiknas. 